\title{
61. The First Discovery of Fossil Crocodile from Central Honshî, Japan
}

\author{
By Nobuo KobataKe*) and Tadao KameI**) \\ (Comm. by Yô K. OKADA, M.J.A., March 12, 1966)
}

In East Asia, no fossil crocodile was ever reported from the area north of Taiwan, except a doubtful one from the Neogene deposits of North Kyûshû. From the lower Pleistocene deposits in Taiwan a fragmental skull of fossil crocodile was introduced into the literature by late Dr. S. Tokunaga in 1936, which was provisionally assigned to Family Tomistomidae or Gavialidae. ${ }^{1), 2)}$ The present paper deals with an excellent and most complete material of fossil crocodile which was found recently in Central Honshû, far north of that island, from the deposits of the same age. It is the first discovery of fossil crocodile in Japan as far as the authors' knowledge is concerned.

Namely, on May 3, 1964, two young men, Mr. K. Ohara and Mr. I. Hitomi, collected some curious bones in the course of fossil hunting in the grounds of Ôsaka University, Shibahara, Toyonaka City, Ôsaka Prefecture. This fact stimulated the senior author and Dr. K. Nakaseko to an investigation of the site with the co-operation of many gentlemen in Ôsaka Univ., Ôsaka City Univ., Univ. of Kyôto, Kôbe Univ., Ôsaka City Mus. Nat. Hist., and so on. In order to make a complete reconstruction of that fossil the site was excavated five times and in the course of the second excavation, Sep. 17, 1964, numerous bones such as skull, jaw, vertebral segments and several others, which are assignable to a single body of crocodile, were found. They were aggregated in a layer of bluish-grey sandy clay belonging to the Plio-Pleistocene Ôsaka Group which has an extensive distribution in Ôsaka and the surrounding areas.

The site, where the crocodile was found, is located on a hill named Machikane-yama which has a height of $77.3 \mathrm{~m}$ above the sea level and easterly continues to the Senri-yama hill where the Ôsaka Group is typically distributed. The Ôsaka Group observed there is composed mainly of beds of clay, sand and gravel in alternation with occasional intercalations of tuff layers providing a good key to the decision of stratigraphical horizon. In addition to them, eight layers

*) Inst. Geol. Sci., Coll. Gen. Educ., Ôsaka, Univ.

**) Inst. Geol. Min., Fac. Sci., Univ. of Kyôto.

1) Tokunaga, S. (1936): Jour. Geol. Soc. Jap., 43, 432.

2) Lin, C. C. (1963): Rep. Histrico-Geogr. Studies of Taiwan, 14, 1-92. 
of marine clay, which have great lateral continuity, are also found within them, and are named Ma 1 to $\mathrm{Ma} 8$ beds in ascending order. ${ }^{3)}$

According to Dr. S. Ishida and Mr. T. Yokoyama, by whom the area was investigated in detail, the sandy clay bed of about $2 \mathrm{~m}$ in thickness, from which the crocodile was dug up, is interbedded with dark grey tuff, or what is called "Kasuri tuff", which is frequent in hornblende and is clearly indicative of a stratigraphical horizon. Namely, the sandy clay bed is thought to be a horizon stratigraphically between $\mathrm{Ma} 7$ and $\mathrm{Ma} 8$ marine clay beds which constitute the upper part of the group, probably early Pleistocene in age (Fig. 1).

A comparative osteological study was carried on by the junior author and Mr. E. Matsumoto ${ }^{4)}$ and the Kälin's proportional indexes of the crocodile skull was used in comparing our skull with other recent and fossil ones. The measurements and the indexes are given below for reference.

Distance of the outermost extremities of Condyli maxillares with each

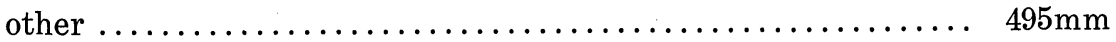

Distance from the posterior extremity of Condylus occipitalis to the anterior extremity of snout...................... $1046 \mathrm{~mm}$

Breadth of snout in the anterior ends of Orbita ........... $331 \mathrm{~mm}$

Length of snout from the anterior end of Orbita to the anterior end of snout .......................................... $776 \mathrm{~mm}$

Length of skull from the posterior end of skull roof to the anterior end of snout .................................... $1014 \mathrm{~mm}$

The least breadth of Spatium interorbitale ............ $50 \mathrm{~mm}$

Length of Orbita ......................................... $92 \mathrm{~mm}$

(left) $95 \mathrm{~mm}$

Length of skull roof ........................... $127 \mathrm{~mm}$

Posterior breadth of skull roof ...................... $234 \mathrm{~mm}$

Anterior breadth of skull roof...................... $187 \mathrm{~mm}$

Breadth of skull in the region of Columna postorbitalis ..... $366 \mathrm{~mm}$

Breadth of Orbita .................................. $88 \mathrm{~mm}$

(left) $85 \mathrm{~mm}$

Width of opening of nasalis externa ............... $73 \mathrm{~mm}$

Length of opening of nasalis externa ............... $58 \mathrm{~mm}$

Length of Choana .............................. $31 \mathrm{~mm}$

Width of Choana............................... $44 \mathrm{~mm}$

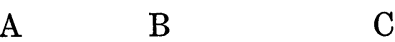

1 Length-breadth index of skull $\quad 47.32 \quad 33.70-46.10 \quad 38.90-41.80$

2 Length-breadth index of snout $\quad 42.76 \quad 22.54-39.00 \quad 30.50-39.95$

3 Skull-snout length index $\quad 76.59 \quad 72.45-76.10 \quad 68.50-74.60$

$4 \begin{aligned} & \text { Length-breadth index of inter- } \\ & \text { orbital space }\end{aligned} \quad 53.57 \quad 15.62-50.00 \quad 28.08-58.50$

3) Itihara, M. (1960): Earth Science, No. 49, 15-25.

4) Kobatake, N. et al. (1965): Quaternary Research, 4 (2), 49-58. 
5 Breadth-length index of skull roof

6 Skull-skull roof breadth index

7 Breadth index of skull roof

$54.15 \quad 58.80-85.00 \quad 58.48-66.98$

$51.09 \quad 46.60-68.00 \quad 45.95-65.40$

$79.00 \quad 66.85-85.00 \quad 70.80-87.20$

8 Skull-orbit index

$9.21 \quad 10.42-13.36 \quad 11.75-15.74$

9 Breadth-height index of condyl

10 Length-breadth index of external nasal opening

$95.30 \quad 62.00-83.70$

$59.05-87.00$

$125.80 \quad 66.70-96.20 \quad 70.72-90.50$

$92.59 \quad 69.00-79.00 \quad 64.20-78.97$

11 Length-breadth index of orbit

$70.47 \quad 67.60-152.00$

$68.20-128.25$

12 Length-breadth index of Choana

A: Present material B: Tomistoma schlegeri ${ }^{5}$

C: Crocodile cataphractus ${ }^{5}$

As a result, the generic position of the present fossil crocodile is given in Tomistoma for the following reasons.

The skull has a long and narrow snout and its surface is marked with less prominent festoon-like ornamentation. The nasal bones are wedge-shaped and located far back from the nasal opening. The premaxilla-maxilla suture observed on the palatal side is $\mathrm{W}$-shaped, the teeth of the upper jaw are $5+16$ in number on each side. These characters coincide with the diagnostic features of the recent Tomistoma schlegeri Müller. However, as many other characters different from those of the recent and fossil forms are observed, the present fossil crocodile was classified as a new species under the name of Tomistoma machikanense Kamei and Matsumoto. Namely as shown in the Table above, the indexes of the present material are very close to those of the recent $T$. schlegeri Müller or Crocodile cataphractus Cuvier, but this material is quite different from those two living forms in having a larger size and a more rounded orbit form and in general features of temporal openings. The anterior part of the lower jaw was unfortunately broken off and only ten teeth remained on each side.

In the axial skeleton, twenty-nine vertebrae from the atlas to the anterior segment of caudal were found and their total length is measured at about $285 \mathrm{~cm}$, but no other vertebral column in the tail region was found. If now the length of the lost tail region is taken into consideration, that crocodile may have measured about $8 \mathrm{~m}$ in length from the anterior end of the nose to the posterior one of the tail.

In addition to them, the materials at hand include four cervical and ten dorsal ribs of the right side, four cervical and three dorsal ribs of the left side, shoulder and pelvic girdles on both sides, humerus, ulna, radius, three carpus, three metacarpus and two manus of the right side, fragmental femur, some tarsals, metatarsals and phalanges of the left side and thirty-two sheets of dermal plates.

5) Kälin, J. (1933): Zool. Jahrb., Vol. 57, F., pp. 537-714. 


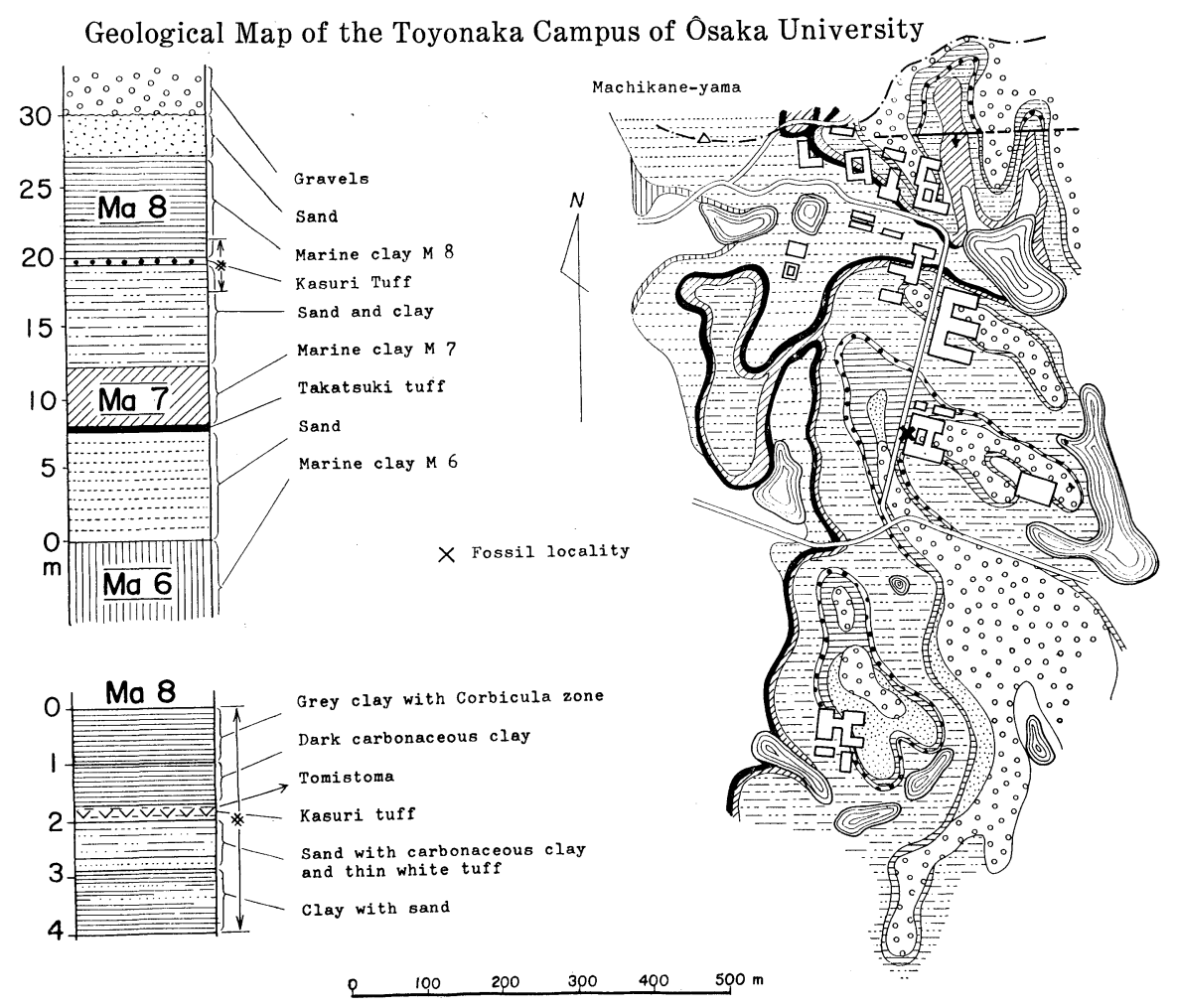

Fig. 1.

It is an interesting fact that some paleopathological evidences are observed in that crocodile. One is an abnormal development found in a dorsal rib and the other is a fracture and a healing up marked in the ulna and radius. Moreover, three pebbles of well polished liparitic and cherty rocks between 1 to $3 \mathrm{~cm}$ across were found associated with the vertebral bones in situ and they are regarded as gastrolith. From the excavation conducted for five times, it is clarified that the bones of the present crocodile were entombed in a restricted patch of area and they were arranged nearly parallel with an assumed water current in a general N-S trend. Therefore, it may be concluded that the crocodile was living near the site of its occurrence and transported not far off immediately after its death.

The sandy clay bed, from which the crocodile was found, is rich in plant and shell remains at the upper bituminous clay part and at the lower sandy part respectively. By Dr. S. Kokawa, some fruit of Trapa (Eutrapa) macropoda Miki, T. (Stipitra) tetragona Miki, Nelumbo nucifera Miki, some shoots of Paliurus nipponicus Miki, 


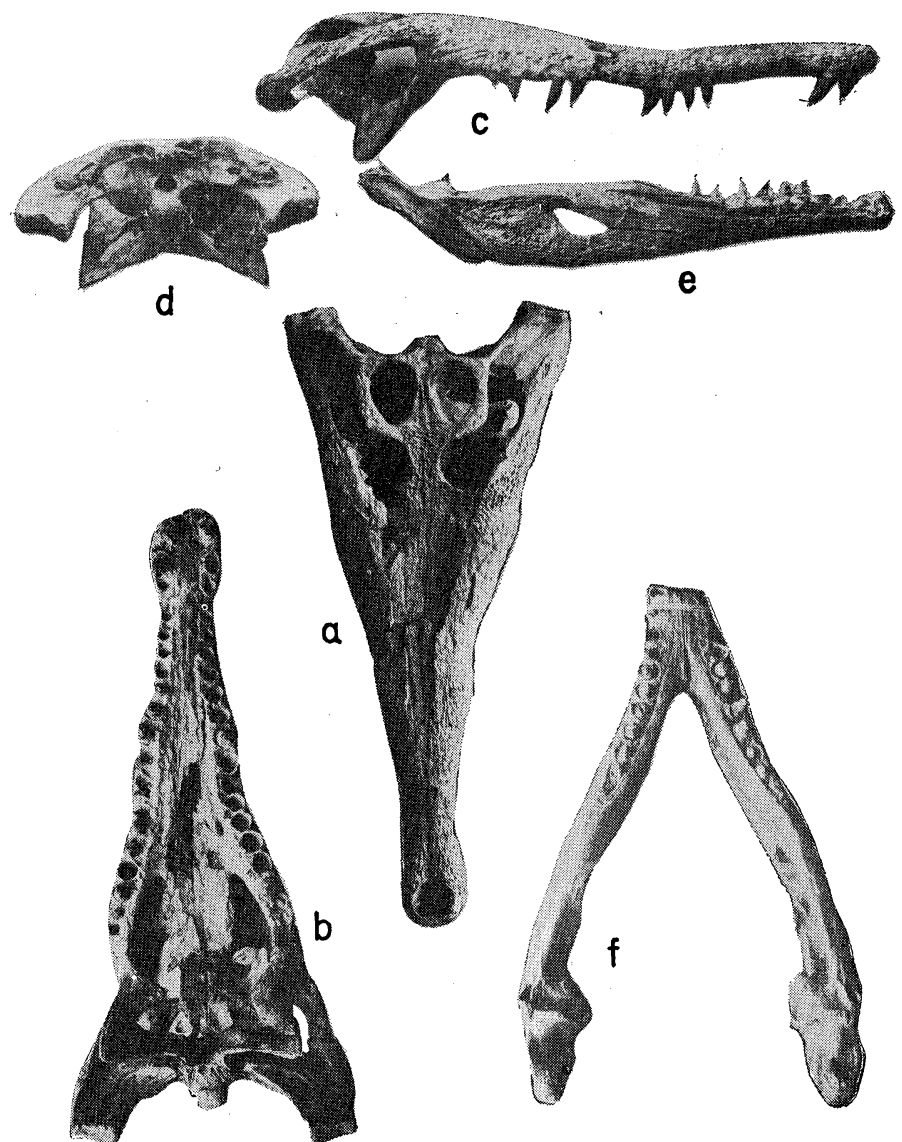

Fig. 2. Tomistoma machikanense Kamei and Matsumoto $\times 1 / 20$ approximately.

a: restored skull in dorsal view. b: ventral view of skull.

c: right side view of skull. d: hind view of skull.

e: external side view of right jaw. f: dorsal view of jaw.

seeds of Sapium sp. and Scirpus sp. were discriminated in the plant remains. The shells were identified by Mr. H. Kajiyama as follows: Cristaria plicata spatiosa (Clessin), Lanceolaria oxyrhincha (v. Martin), Lymnium (Lymnium) biwae (Kobelt), L. (L) brandi (Kobelt), L. (L) reinianum (Kobelt), L. (L) hirasei (Haas), Anodonta lauta v. Martens, Corbicula sandai Reinhardt, Viviparus longispira (Smith). They are all inhabitants of fresh water and live only in Lake Biwa and River Yodo. From the above-mentioned fact it is safe to assume that immediately after the death the crocodile was suddenly buried due to the turbulent in the swampy environment near an inner margin of the paleo-Ôsaka bay. Although the recent crocodiles allied to the present form are peculiar to tropical and 
subtropical regions, such as the Malay peninsula, Sumatra, and Borneo, no evidence of such warmer condition is found in the sandy clay bed, from which Tomistoma machikanense occurred. On the other hand, by an analysis of the pollens contained in the sandy clay bed, Miss A. Tai and Mr. I. Ônishi poited out that Alnus, Fagus, Pinus, and Cryptomeria, which are indicatives of a temperate environment in the case of the Ôsaka Group, are frequently found. Moreover, though it is well known that no evidence for the development of tropical and subtropical environment is ascertained throughout the Osaka Group s. str., it may be said from the general floral assemblage that the sandy clay bed in question was deposited under the influence of a more temperate or warmer environment than those indicated by the strata stratigraphically above and below it.

On the basis of the evidences obtained from the excavation it may be concluded that the crocodile was distributed up to $35^{\circ} \mathrm{N}$ at least in Japan under the influence of climatic fluctuations during the early Pleistocene.

As stated above, the preservation of this fossil crocodile is so extraordinarily good that it seems to afford adequate material for various researches from different viewpoints. Therefore, beside the geological and paleontological studies, a histological, anatomical and biochemical collabolative research on the bones and teeth is being made by the members of the Machikane-Wani Research and Preservation Committee of Ôsaka University.

The authors wish to express their sincere thanks to Prof. S. Akabori, President of Ôsaka University, for his encouragement given throughout the excavations of the fossil and the publication of this short paper. 